\title{
Ortaokul Öğrencilerinin Müzik Dersine Yönelik Görüşleri (Niğde İli Örneği)
}

\section{The Opinions of Students in Secondary School About Music Lesson (Niğde Province Sample)}

\author{
Damla Bulut, Doç. Dr. Niğde Üniversitesi Eğitim Fakültesi GSEB Müzik Eğitimi ABD, dbulut@nigde.edu.tr \\ Yasemin Gülsoy, Öğretmen, Aksaray Gaziemir Yakacık Ortaokulu, yasemin.gulsoy@hotmail.com
}

\begin{abstract}
öZ. Araştırmanın amacl, ortaokul öğrencilerinin müzik dersine ilişkin görüșlerini "Niğde İli Örneği" üzerinden belirlemek, bu görüşler doğrultusunda öğrencilerin mevcut müzik derslerine yönelik tutumlarını ortaya koymak ve etkili bir müzik dersi için öneriler geliştirmektir. Araştırma betimsel niteliktedir. İlgili veriler uzman görüsşleri doğrultusunda araştırmacılar tarafından geliştirilen yapılandırılmamış görüşme formu ile toplanmıştır. Elde edilen nitel verilerin çözümlenmesinde içerik analizi kullanılmıştır. Araştırmanın evrenini 2012-2013/2013-2014 eğitim öğretim yıllarında Niğde İl Milli Eğitim Müdürlügü̈ne bağlı ortaokullarda öğrenim gören öğrenciler, örneklemini ise; bu öğrenciler arasından tesadüfî örneklem yoluyla seçilen Alparslan, Kemal Aydoğan, 19 Mayıs, 23 Nisan Havacılar, Selçuk, Atatürk ve Cumhuriyet Ortaokullarının 5, 6, 7 ve 8. sınıfında öğrenim gören 644 öğrenci olușturmaktadır. Araștırma bulguları doğrultusunda; Ortaokul 5. sınıf öğrencilerinin çoğunluğunun müzik dersini zevkli bulduğu, müzik dersini ve müzik öğretmenini sevdiği; Ortaokul 6. sınıf öğrencilerinin çoğunluğunun müzik dersini sevdiği, müzik dersini eğlenceli ve önemli bir ders olarak gördükleri; Ortaokul 7. sınıf öğrencilerinin çoğunluğunun müzik dersini sevdiği, müzik dersini eğlenceli buldukları ve müzik dersi ile ilgili davranışlarını olumlu olarak gördükleri; Ortaokul 8. sınıf öğrencilerinin çoğunluğunun müzik dersini sevdiği, müzik dersini rahatlatan ve önemli bir ders olarak gördükleri sonuçlarına ulaşılmıştır. Ayrıca ortaokul 5, 6, 7 ve 8. sınıf öğrencilerinin konuya ilişkin görüşlerinin ders, öğretmen ve öğrenci odaklı olduğu, bu görüşlerin de büyük çoğunlukla duyuşsal alana yönelik olduğu tespit edilmiştir.
\end{abstract}

Anahtar Kelimeler. Ortaokul, Müzik, Müzik Dersi, Öğrenci Görüşü.

\begin{abstract}
The aim of research is to determine the opinions of secondary school students in Niğde District about music lesson, and show the current status of available music lessons and also bring forward a proposal for music lessons. Research is descriptive quality. Related data has been collected through unstructured interview form that was developed by researchers according to ideas of specialists. In the analysis of qualitative data, content analysis has been used. The universe of research consists of secondary school students who keeps learning during the education periods of 2012-20013/2013-2014 in secondary schools of Niğde Province under authority of Directorate of National Education; the sample of research consists of 644 students, who have been randomly selected and study in 5th, 6th, 7th and 8th classes from secondary schools Alparslan, Kemal Aydoğan, 19 Mayıs, 23 Nisan Havacılar, Selçuk, Atatürk and Cumhuriyet. According to findings in this research, the majority of students in 5th class of secondary school finds music lesson pleasurable, loves music lesson and music teacher; the majority of students in 6th class likes music lesson and finds music lesson important and funny; the majority of students in 7th class of secondary school likes music lesson, finds music lessons funny and music lessons related behaviors they see as positive; the majority of students in 8th class likes music lesson and finds music lesson relaxing and important. Moreover, the opinions of students from classes 5, 6, 7 and 8 of secondary school depend on lesson, teacher and student, so that these ideas focus on affective field.
\end{abstract}

Keywords. Secondary School, Music, Music Lesson, Opinion of Students.

\section{SUMMARY}

Purpose and Significance: The goal of this study is to determine the ideas of secondary school students about music lesson by using the sample of Niğde city, then propound the attitudes of these students to current music lessons in secondary school in the direction of these ideas, and finally bring forward a proposal for an effective music lesson. This study has a significance in order to determine the ideas of secondary school students about music lesson by using the sample of Niğde city and develop an effective music lesson in the direction of students' attitude to music lessons. 
Methodology: The study is a field research with screening model. A literature screening has been carried out in order to create the theoretical basis. In addition, expert views have gained the ideas of secondary school students in sample group to music lessons by using unstructured interview form that was developed by researchers. In the analysis of qualitative data, content analysis has been used. Obtained findings have been interpreted and then the outcomes have been delivered. Total 644 students, who study during educational periods 2012-2013/2013-2014 in the schools that were selected between secondary schools under Provincial Directorate of National Education in Niğde by random sampling, are the sample of this study.

Results: According to findings from this study, the students in classes 5, 6, 7 and 8 focus on lesson, teacher and student, and these ideas depend on affective field.

Discussion and Conclusion: According to study findings, the students in class 5 find music lesson pleasurable first and love music lesson and music teacher; the students in class 6 love music lesson first and think it significant; the students in class 7 love music lesson first and have positive behaviors for music lesson; the students in class 8 love music lesson and find music lesson pleasurable and significant. Also, the students in classes 5, 6, 7 and 8 focus on lesson, teacher and student, therefore their ideas depend on affective field.

\section{GíRIş}

Bireyler doğumundan ölümüne kadar geçen süreçte yakın çevrelerinden başlayarak hayata dair olup biteni gözlemekte, gözlemlerine dayalı olarak hayatı anlamlandırmakta, tanımlamakta ve çözümlemekte, dolayısıyla sürekli olarak bir öğrenme faaliyeti içerisindedirler. Bu durum bireylerin hem birey olarak gelişimine hem de toplumun gelişmesine katkı sağlamaktadır. Çünkü her birey kendi zihinsel süreçleri, hazırbulunuşluk düzeyi ve donanımı doğrultusunda hayatı anlamlandırma, tanımlama, çözümleme yani öğrenme faaliyetlerini gerçekleştirir, bireysel etkileşimler sonucu farkında olmadan kendi tecrübelerini topluma aktarır.

Çağdaş dünya koşulları sürekli değişip gelişirken, bu değişime ve gelişime ayak uydurmak isteyen bütün toplumlarda bireyleri bazı sorumluklar beklemektedir. Girişimcilik, yaratıcılık, üretkenlik, kendine güvenme, sorgulama, eleştirme, tartışma, muhakeme yeteneğine sahip olma olarak sıralanabilecek bu sorumluluklar ancak bireylerin çağdaş ve çok boyutlu eğitim almaları ile yerine getirilebilir (Aksu, 2005:25). Söz konusu eğitim kapsamında sanat eğitimi büyük bir yere ve öneme sahiptir. Çünkü sanat eğitimi, bireyin içinde yaşadığı dünyayı kavramada, karşılaştığı problemleri çözmede, gördüğü, hissettiği şeylere karşı tepki göstermede son derece önemli roller üstlenir ve bir bütünlük içerisinde düşünüldügünde birey ve toplum için can damarı durumundadır (Gel, 1994).

Eisner'e göre (1972) nasırlı olmak, duyarsız olmak, katılaşmaktır. Nasırlı olan birinin sinir uçları yaşadığı dünyayı hissetmesini engelleyen sert bir deriye dönüşmüştür. Güzel sanatlar alanlarında elde edilen deneyimler, bir tür nasır kazıyıcıdır. Sanat bir kişinin sinir uçlarının daha keskin, cevap verebilir hâle gelmesini ve dünyayı anlamlı kılmasını sağlar. Boyer ise uygarlığın başlangıcından itibaren bireylerin müziği, dansı ve görsel sanatları neșe ve kederlerini aktarmak için kullandıklarını, bu doğrultuda güzel sanatların uygarlığın ölçülebildiği en önemli araçlar olarak karşımıza çıktığını belirtmektedir (Özsoy, 2003:20-22). Bu araçlar içerisinde müzik, her insanın yaşantısında var olan, hoşa giden, mutluluk getiren, sevinç ve heyecan veren önemli bir olgudur. Bu olgu aracılığıyla insan kendi duygularını, düşüncelerini kısaca içinde var olanları dışa vurup karşısındakine aktarabilir, aynı şekilde karşısındakinin duygularını, düşüncelerini anlayabilir ve yorumlayabilir. Dolayısıyla müzik, bireyin toplumsallaşmasında, doğuştan getirdiği yaratıcılık özelliğinin gelişmesinde, kendini ifade etmesinde, anadilini öğrenmesinde, zekâ gelişiminde önemli katkılar sağlayan unsurların en önemlisidir denilebilir (Uçal Canakay, 2006: 297).

Müzik, sadece büyük müzik ustalarına özgü bir ilham kaynağı değildir. Dünyaya yeni gelmiș bir bebek bile, ellerini ve kollarını ritmik hareketler ile oynatır. Buna göre müzik; Herkesin âşık olduğu o evrensel güzelliğin dünyadaki farklı yansımaları arasındaki bağı sağlayan bütün sanatların ortak dili olarak tanımlanabilir (Khan, 1994:14). Uçan'a göre (2005:10) müzik, çocuğun veya diğer bireylerin duygu, düşünce ve tasarımlarını, yaşadıkları durum, olgu ve olaylara göre bir güzellik 
anlayıșına uygun olarak belli bir amaç ve yöntemle, ișlenmiș seslerle anlatan estetik bir bütündür. Gedikli'ye göre (2007:16) müzik ise; sessiz sonsuzluğun ölçülenimi (sayımlama) içinde seslerle düşünüş, duyuş, biliş, söyleyiş, çalış ve devinişten oluşan bütünü yorumlayan iş etkinliğidir. Coğrafyalar, iklimler ve kültürlerin farklılığı yorumlayış etkinliklerinin de farklılığını ve zenginliğini ortaya koyar. Bu etkinlik ritim, ezgi ve armoni ile anlam kazanır, insanlara ulaşır. Dolayısıyla insanlar hangi coğrafyada olurlarsa olsunlar, hangi iklimlerde yaşarlarsa yaşasınlar ve hangi kültür içinde olurlarsa olsunlar ortak değer ve ortak paydada birleşirler. Çünkü müziğin, insandan insana uzanan evrensel bir dil olması, dili, dini ayrı insanları aynı ezgide birleştirecek güce sahip olması, onu, diğer sanat dalları içinde ayrıcalıklı kılmaktadır. Bu nedenle müzik tüm sanat dalları içinde, insan ruhu üzerinde en derin etkiyi bırakan sanat olduğu kabul edilmektedir (Biber Öz, 2001: 102).

Müzik, fonetik sanatların en önemli dallarından biridir. Müziğin ses ve ritim gibi en temel ögelerinin yeniden sentezlenmesi özelliğine sahip olması onu diğer sanat dallarından ayırmaktadır. Fonetik sanatlardan biri olarak duygu, düşünce, tasarım ve izlenimleri belli bir güzellik anlayışına göre düzenli ve uyumlu seslerle anlatan müziğin insan ve toplum yaşamında önemli işlevleri bulunmaktadır (Kocabaș, 1997:141). Bu işlevler bireysel, toplumsal, kültürel, ekonomik ve eğitimsel olarak beş ana madde şeklinde sıralanabilir. Uçan'a göre (2005:13); Müziğin bireysel işlevi, bireyin dengeli, başarılı, duyarlı ve mutlu olması için bilișsel, duyuşsal ve devinişsel davranışları üzerinde olumlu izler bırakan, müziksel uyarılma ve tepkide bulunma biçimlerini kapsar. Müziğin toplumsal işlevi, bireyler, birey ile toplum, toplumsal kesimler ve toplumlar arasında tanışma, anlaşma, dayanışma, kaynaşma, paylaşma, yaklaşma, işbirliği yapma, birleşme ve bütünleşme sağlamasında müziğin oynadığı rolleri kapsar. Müziğin kültürel işlevi, kültürü artırıcı, kültürel özellikleri kuşaktan kuşağa aktarıcı, kültürler arası ilişkileri zenginleştirici müziksel birikim ve etkinlikleri kapsar. Müziğin ekonomik işlevi, sanatsal öz korunmakla birlikte müzik alanında giderek belirginleşen sunu-sistem, üretim-dağıtım-tüketim ilişkilerinin ağır bastığı çalışma ve düzenlemeleri kapsar. Müziğin eğitimsel işlevi, bireysel, toplumsal, kültürel ve ekonomik işlevlerin düzenli, sağlıklı, etkili, verimli ve yararlı olmasına yönelik müziksel öğrenme öğretme etkinlikleri ile bunlara ilişkin düzenlemeleri kapsar. Kısaca, müziğin bireysel işlevi, bireyin sağlıklı ruhsal, kültürel ve kişilik gelişimini, müziğin toplumsal işlevi, bireyin diğer bireylerle iletişim ve etkileşimde bulunarak onlar ile anlaşmasını-kaynaşmasını, müziğin kültürel işlevi, kültürün devamına yönelik olarak kültürel birikimi aktarmayı ve taşımayı, müziğin ekonomik işlevi, müziksel yaratma-üretme-tüketme-dağıtma-korunma durumlarını, müziğin eğitimsel işlevi ise diğer tüm işlevlerin işleyişini nitelikli bir şekilde sağlamaya yönelik müziksel öğretme ve öğrenme süreçlerini kapsamaktadır denilebilir.

Müziğin, çocuğu yaratıcılığa yöneltmek, dikkatini geliştirmek, ilgi ve yeteneğini sergilemek, toplumun bir bireyi olduğunu fark ettirmek, yaşadığı çevreyi algılamasını sağlamak, düşüncelerini davranışa dönüştürmek gibi sıralayacağımız hedefleri vardır (Dinçer, 1992: 77). Doğduğu çevrede müzikle etkileşim içinde olan insan, dinleme, benzetme, oynama, mirldanma, tempo tutma, islık çalma, söyleme, tıngırdatma, beğenme, çalma, yaratma, eleştirme ve benzerleri müziksel davranışları kazanır. Bu davranışların temelinde "müzikle anlaşma" vardır. Böylelikle müzik insana kendini tanıma, kendini gerçekleştirme, kendini anlatma, kendini aşma olanağı verir (Say, 2006: 19). İlköğetim çağındaki çocukların günlük yaşantılarındaki tekdüzeliğin giderilerek, bedensel, ruhsal ve zihinsel sağlıklarının korunabilmesi ve üzerlerindeki baskıların biraz olsun hafiflemesi için düzenli olarak yapılan müziksel etkinliklere yönelmeleri önemlidir (Çilden, 2001: 2). Söz konusu müziksel davranışların kazanılmasında, nitelikli bir şekilde kullanılmasında, geliştirilmesinde, değiştirilmesinde ve hatta aktarılmasında müzik eğitiminin rolü büyüktür.

Müzik eğitimi, bireyin müziksel davranışlarında kendi müziksel yaşantıları yoluyla ve kasıtlı olarak istendik değişmeler oluşturma sürecidir. Bu süreçte bireyin; müziksel algılama yeteneğinin farklılaşıp çeşitlenmesi, belli koşullandırmaların ürünü olan tek yanlı müzik yapma, üretme ve dinleme alışkanlıklarından kurtulması, müziğin çeşitli, çok yönlü tını özelliklerine, yapı taşlarına, kuruluş biçimlerine ve etki alanlarına açılması, müzikle ilişkilerinde daha yüksek düzeyde bir bilinçlilik ve eleştirme gücü kazanması, müzikle ilgili bir çalgı, bir kitap ya da kaynak seçiminde ve bir müzik eserini ya da etkinliğini eleştirip değerlendirmesinde yardımcı olacak bireysel müzik yeteneklerinin geliştirilmesi, değişik türdeki müzik çalışma ve etkinliklerine etkin katılımının sağlanması amaçlanmaktadır (Uçan, 1997:15-16). 
19. yüzyılda ABD’li müzik eğitimci Mason müzik eğitiminin amacını, profesyonel müzisyenler yetiştirmek değil ama müzikten anlayan bireyler yetiştirmek, şeklinde ortaya koymuştur. Hatta çocuklara okuma-yazma öğretildiği gibi müziğin de öğretilmesi gerektiğini belirtmiştir (Göğüş, 2008: 370-371). Çilingir'e göre (1990) müzik ile ilgilenen çocukların anlatım güçleri, sorumluluk duyguları ve özgüvenleri gelişir (Akgül Barış, 2002:44). Ayrıca etkin ve bilinçli bir müzik eğitimi çocuğun yaratıcı gücünü uyandırdığı gibi, onun bu yöndeki yeteneklerinin de gelişmesini ve zenginleşmesini sağlar. Bu bağlamda çağdaş eğitimin vazgeçilmez unsurlarından biri olan müzik eğitiminin amaçları içerisinde; insan zekâsını ve yeteneklerini en üst düzeyde geliştirmek ve yetkinleştirmek vardır. Eğitim sürecinin bir boyutu olarak müziğin, bireyin, zekâ gelişimi ve bilişsel başarısı üzerindeki etkileri de yıllardan beri çok çeşitli araştırmalara konu olmuştur. Müzik eğitiminin bireyin duyuşsal ve devinişsel davranışlarındaki olumlu etkilerinin yanı sıra, bireyin bilişsel öğrenmelerinde de önemli ölçüde etkili rol oynadığı bir çok araştırmayla kanıtlanmıştır (Şendurur ve Akgül Barıș, 2002: 166). Örneğin, Wilson (1998) müziksel etkinliklerin çocukların fiziksel koordinasyon, zamanlama, hafıza, görsel, işitsel ve dil becerileri üzerinde anlamlı etkilerinin olduğunu, konsantrasyon ile sosyal ve bireysel farkındalıklarını arttırdığını gözlenmiştir. Rauscher (1997) müzik dersi alan öğrencilerin öğretim yetenek testinden aldıkları puanların müzik dersi almayanlardan oldukça yüksek çıktığını vurgulamıștır. Bunun yanında müziğin üstünlük alışkanlıkları sağladığını, ortak müzik çalıșmalarının takım ruhunu ve işbirliği becerilerini geliştirdiğini belirtmiştir. Gallup ise (1997) müziğin çocukların hızlı ve doğru karar verme becerilerini geliştirdiğini, eylem içerisinde kendilerini izleme iç görüsünü sağladığını, çocukları takım içinde çalışma, iletişim, benlik saygısı, yaratıcı düşünme, hayal etme ve buluş konusunda geleceğe yönelik olarak hazırladığını tespit etmiștir (Kocabaş ve Selçioğlu, 2003:140).

Yapılan bazı çalışmalar da göstermiştir ki, tüm çocuklar müzik yeteneğiyle doğarlar. Örneğin Value Music, n.d. iki aylık bebeklerin, ses perdesi, şiddeti ve annelerinin söylediği şarkıların melodilerini, dört aylık olan bir bebek ise bunlara ek olarak ritmi bazı alıştırmalar yapılarak tanıyabildiklerini (Göğüş, 2009:93), Radocy ve Boyle Petzold'un, müziksel algılama ile ilgili yaptığı araştırmada ilk altı sınıftaki ilköğretim düzeyi çocuklarına ses kalıpları ritim ve cümleleme testleri uyguladığını, 6. sınıf düzeyinde müziksel algılamada büyük bir gelişme olduğunu, bu gelişmeye müzik eğitiminin ve okul dışı deneyimlerin önemli etkisinin bulunduğunu tespit ettiğini ve müzik öğretiminde ezbere müzik öğrenme yerine düşünerek/akıl yürüterek yapılan öğrenmeyi önerdiğini (Göğüş, 2009:25), Sadie (1980) Sergeant'ın profesyonel müzisyenlerle yaptığı bir araştırmada ise, mutlak (absolute) perde yeteneği ile bilinçli bir müzik eğitiminin başlama yaşı arasında ilişki olduğunu, bu eğitimi almaya 2 ile 4 yaşında başlayanların (profesyonel müzisyenlerin) \%92'sinin mutlak perde yeteneğine sahipken 12-14 yaşlarında başlayanların sadece \%6'sının böyle bir yeteneğe sahip olduklarını, daha büyük yaşlarda eğitime başlayanlar arasında ise, mutlak perde veya mutlak tonalite ayırma yeteneğine sahip olan birine rastlanmadığını belirtmişlerdir (Göğüş, 2009:93).

Müzik eğitimi, aslında bir bütün olmakla birlikte, çeşitli kollara ve her bir kol da kendi içinde çeşitli dallara ayrılır. Çünkü müzik eğitimi, ağırlıklı olarak kapsanan temel davranış ve içerik, kullanılan araç ve gereç, izlenen yöntem ve teknik, gerçekleştirilen ortam ve düzey, öngörülen aşama ve süre bakımından kendi içinde çeşitlilik gösterir ve her bir çeşide bağlı olarak değişik biçimlerde adlandırılır. Kolu, dalı, kapsamı ve içeriği, aracı ve gereci, yöntemi ve tekniği, ortamı ve düzeyi, aşaması ve süresi ne olursa olsun, müzik eğitimi, temelde genel, özengen (amatör), mesleki olmak üzere, üç ana amaca yönelik olarak düzenlenip gerçekleştirilir. Genel müzik eğitimi, okul öncesinde, temel, orta ve yüksek eğitim düzeylerinde okul ya da program ayrımı gözetilmeden her düzeyde, her aşamada, her yaşta, herkese yönelik verilen müzik eğitimidir (Uçan, 2005:31-41).

Toplumdaki her bireye yönelik olan genel müzik eğitiminin, bireylerde beklenilen müziksel bilgilerin, bilincin ve duyarlılığın oluşmasında büyük önemi vardır. Bunun yanında istenilen niteliklerde bireyler yetiştirilmesi için genel müzik eğitimi kaçınılmazdır. Aksi takdirde bu beklentileri bireylerin gerçekleştirmesi ve toplumun gelişimine katkı sağlaması söz konusu değildir. Bu nedenledir ki genel müzik eğitimi ilköğretim düzeyinde zorunlu bir eğitimdir ve müzik dersi de zorunlu bir derstir (Aktaş ve Bulut, 2012:419). İlköğretim (ilkokul-ortaokul) müzik dersinin amacı çocukların bilişsel, duyuşsal, devinişsel ve sosyal alanlarda gelişimini sağlayarak nitelikli bir müzik kültürü oluşturmaktır (Kocabaş ve Selçioğlu, 2003:139). 
Müzik, insanın gelişimine katkı sağlaması yönüyle ele alındığında eğitimin bir aracı olarak görülmekte ve müziksel olmayan bir amacı gerçekleştirmektedir. Müzik yapan-yaratan insanda estetik bir yaşantının oluşması ise müziğin kendisini bir amaç haline gelmektedir. Bu bağlamda müzik, hem müziksel hem de müziksel olmayan amaçları gerçekleştirmek için programlarda yer almaktadır (Göğüș, 2008: 370).

Müzik eğitiminin söz konusu amaçlarına tam olarak ulaşabilmek için nitelikli bir müzik eğitiminin tasarlanması, gerçekleşmesi ve uygulanması gerekmektedir. Bu süreçte temel alınan başlıca kaynak şüphesiz ki müzik dersi öğretim programıdır. Ülkemizde genel müzik eğitimi kapsamında ilköğretim müzik dersi öğretim programı kullanılmaktadır. Bu program Cumhuriyet döneminden itibaren pek çok değişim geçirmiş, son olarak 2006 yılında yapılandırmacı yaklaşım doğrultusunda hazırlanmıș ve Milli Eğitim Bakanlığı (MEB) İlköğretim Genel Müdürlüğünce teşkil edilen Müzik Özel İhtisas Komisyonu tarafından geliştirilerek 2007-2008 öğretim yılı itibariyle de yürürlüğe girmiștir.

Yapılandırmacı anlayış doğrultusunda programda; Öğretmeye değil, öğrenmeye önem verilmiş, ireylerin farklılığı kabul edilmiş, öğrencilerin araştırıcılığı desteklenmiş, öğrenme sürecinde daha önceki yașantılara önem verilmiş, öğrenmede performans ve etkinliklere ağırlık verilmiş, öğrencinin nasıl öğrendiği dikkate alınmıș, öğrencinin sosyal bir çevre içerisinde öğrenmesi anlayışı benimsenmiş, öğretimde gerçekçilik ve işlevsellik desteklenmiş, öğrencilere bilgi oluşturma ve deneyimlerinden sonuç çıkarma firsatı verilmiştir. Programın vizyonu, ise öğrencilerin müziği etkinlikler aracılığıyla yaşayarak hayatlarının ayrılmaz bir parçası hâline getirmelerine ve müzik yoluyla;

- Kendisi ve çevresiyle barışık,

- Ulusal ve uluslararası kültürleri tanıyan,

- Vatan ve millet sevgisine sahip,

- Çevresindeki olaylara, değişim ve gelişmelere duyarlı,

- Güzel sanatların her türüne açık,

- Mutlu, kişilikli ve öz güvenli bireyler olarak yetişmelerini sağlamak,

olarak belirlenmiştir (MEB, 2007: 4-5).

Program incelendiğinde genel amaçlar, temel beceriler, öğrenme alanları, kazanımlar, etkinlikler, açıklamalar, öğrenme-öğretme süreçleri ve ölçme değerlendirme boyutlarından oluştuğu görülmektedir. $\mathrm{Bu}$ boyutlar içerisinde etkinlikler boyutunun, öğrenme-öğretme süreçlerinin gerçekleştirilmesi, ilgili öğrenme alanları doğrultusunda gerekli bilgilerin öğrencilere aktarılması ve bu sayede müzik dersi ile istenen kazanımlara ulașılması hususunda önemi büyüktür. deVries (2004) müzik etkinlikleri yolu ile öğrencilerin edindiği kişisel kazanımları:

- Öğrenciler bu yolla enerjilerini boşaltma ve fiziksel ve bedensel olarak rahatlama şansı buluyor,

- Öğrencilerin devinim (motorik) becerileri gelişiyor,

- Öğrencilerin sosyalleşmesi sağlanıyor,

- Öğrenciler kendilerini ifade etmek için firsat buluyor,

- Öğrencilerin iletişimde çok önemli bir öğe olan dinleme becerileri gelişiyor, şeklinde sıralamaktadır (Kılıç, 2012: 2).

Söz konusu kazanımlara ulaşılarak genel müzik eğitiminde başarıya ulaşılabilmesinde öğrencilerin müzik dersine ilișkin tutumları ve görüşleri önemlidir. Eğer öğrenciler müzik dersine karşı olumlu tutum sergiler ve bu derse yönelik görüşleri olumlu olursa bu durum onların ihtiyaçlarını karşılayan bir eğitim-öğretimin onlara verildiğini ve böylelikle, genel müzik eğitiminde istenen başarının gerçekleștiğini ortaya çıkaracaktır. Dolayısıyla öğrencilerin müzik dersine ilişkin duygu ve düşüncelerinin tespiti söz konusu başarıya ulaşılabilmesi için bir gerekliliktir.

$\mathrm{Bu}$ önem ve gereklilik doğrultusunda, araştırmada ortaokul öğrencilerinin müzik dersine yönelik görüşleri incelenmiştir.

\section{Problem Cümlesi}

Araştırmanın problem cümlesi “Ortaokul Öğrencilerinin Müzik Dersine Yönelik Görüşleri Nelerdir?" olarak belirlenmiştir. 


\section{Alt Problemler}

Araştırmanın problem cümlesinin çözümüne ışık tutacak alt problemleri;

1. Niğde İlinde Öğrenim Gören Ortaokul 5. Sınıf Öğrencilerinin Müzik Dersine Yönelik Görüşleri Nelerdir?

2. Niğde İlinde Öğrenim Gören Ortaokul 6. Sınıf Öğrencilerinin Müzik Dersine Yönelik Görüşleri Nelerdir?

3. Niğde İlinde Öğrenim Gören Ortaokul 7. Sınıf Öğrencilerinin Müzik Dersine Yönelik Görüşleri Nelerdir?

4. Niğde İlinde Öğrenim Gören Ortaokul 8. Sınıf Öğrencilerinin Müzik Dersine Yönelik Görüşleri Nelerdir?

şeklinde oluşturulmuştur.

\section{Araştırmanın Amacı}

Araştırmanın amacı, ortaokul öğrencilerinin müzik dersine yönelik görüşlerini, Niğde ili örneği üzerinden belirlemek; bu görüşler doğrultusunda öğrencilerin mevcut müzik derslerine yönelik tutumlarını ortaya koymak ve etkili bir müzik dersi için öneriler geliştirmektir.

\section{YÖNTEM}

Araştırmanın bu bölümünde, araştırma modeli, evren ve örneklem, verilerin toplanması, verilerin çözümü ve yorumlanması konularına yer verilmiştir.

\section{Araştırma Modeli}

Araştırma, tarama modelinde bir alan araştırmasıdır. Kuramsal temellerin oluşturulması aşamasında literatür taraması yapılmıştır. Bunun yanında örneklem grubunda yer alan ortaokul öğrencilerinin müzik dersine yönelik görüşleri uzman görüşleri doğrultusunda araştırmacılar tarafından geliştirilen yapılandırılmamış görüşme formu ile alınmıştır. Elde edilen nitel verilerin çözümlenmesinde içerik analizi kullanılmıştır. Elde edilen bulgular yorumlanarak sonuçlara ulaşılmıştır.

\section{Evren ve Örneklem}

Araştırmanın evrenini Niğde İl Milli Eğitim Müdürlüğü'ne bağlı ortaokullarda öğrenim gören öğrenciler oluşturmaktadır. Araştırmanın örneklemini ise bu ortaokullar içerisinden 20122013/2013-2014 eğitim öğretim yıllarında tesadüfî örnekleme yoluyla seçilen Alparslan, Kemal Aydoğan, 19 Mayıs, 23 Nisan Havacılar, Selçuk, Atatürk ve Cumhuriyet Ortaokullarının 5. sınıfından 147, 6. sınıfından 153, 7. sınıfından 150 ve 8. sinıfından 194 olmak üzere toplam 644 öğrenci oluşturmaktadır.

\section{Verilerin Toplanması}

Araştırmada veriler uzman görüşleri doğrultusunda araştırmacılar tarafından geliştirilen yapılandırılmamış görüşme formu kullanılarak toplanmıştır.

Görüşme formu iki bölüm şeklinde oluşturulmuştur. Birinci bölümde örneklem grubundaki öğrencilere yönelik kişisel bilgiler, ikinci bölümde ise öğrencilerin müzik dersiyle ilgili duygu, düşünce ve davranışlarının belirlenmesine yönelik açık uçlu soru yer almıştır.

Görüşme formu hazırlanırken kapsam geçerliliğine yönelik uzman görüşü alınmış, bir profesör, iki doçent ve üç yardımcı doçentin incelediği uzman değerlendirme formundan sonra görüşme formuna son hali verilmiştir.

\section{Verilerin Analizi}

Uzman görüşleri doğrultusunda hazırlanan form ile yapılan görüşmelerde her bir öğrenci formunda yer alan soruları yazılı olarak cevaplamışlardır. 
Elde edilen nitel verilerin çözümlenmesinde içerik analizi kullanılmıştır. İçerik analizinde veriler kodlanır, temalar bulunur, veriler kodlara ve temalara göre düzenlenir ve tanımlanır. Son olarak da elde edilen bulgular yorumlanır (Yıldırım ve Şimşek, 2006:227-240). Bu çalışmada da yazılı olarak ulaşılan veriler ayrı ayrı incelenerek anlamlı bölümlere ayrılmış ve bölümlere tanımlayıcı isimler yani kodlar bulunmuştur. Böylelikle anlam bakımından ilişkili olan veriler aynı kod (kavram) altında toplanmıştır. Kodlanan veriler bir araya getirilerek kategorize edilmiş ve temalar saptanmıştır.

\section{BULGULAR ve YORUM}

Bu bölümde, örneklem grubundaki öğrencilerin müzik dersine yönelik görüşlerini gösteren dağılımlar (f) frekans ve (\%) yüzde olarak tablolar halinde gösterilmiş ve yorumlanmıştır.

Tablo 1. Örneklem Grubundaki Ortaokul 5. Sinıf Öğrencilerinin Müzik Dersine Yönelik Görüşleri

\begin{tabular}{|c|c|c|c|}
\hline Görüşler & İfade Eden Öğrenciler & f & $\%$ \\
\hline Müzik dersi zevkli & $\begin{array}{l}\text { Ö }(2,6,7,9,14,15,17,18,19,20,23,26,27,28, \\
30,32,34,35,37,38,39,40,44,49,51,53,55,56, \\
57,58,60,61,64,65,66,68,69,70,71,72,73,76, \\
78,80,81,82,83,86,87,88,89,92,95,96,97,99, \\
101,102,103,104,105,107,109,110,111,112, \\
116,119,121,124,125,126,129,130,133,134, \\
136,137,138,139,140,142,144,145,146)\end{array}$ & 85 & 57,8 \\
\hline Müzik dersini seviyorum & $\begin{array}{l}\text { Ö }(5,9,10,11,12,13,15,19,20,21,22,25,28, \\
30,31,33,34,35,36,37,41,42,44,46,47,48,49, \\
50,51,54,57,61,62,63,66,67,68,69,71,74,75, \\
76,78,79,80,82,83,85,87,88,89,90,97,98,99, \\
100,101,102,103,106,107,109,110,111,112, \\
113,114,115,120,123,126,127,128,129,134, \\
135,136,137,138,140,141,143,144,145)\end{array}$ & 84 & 57,1 \\
\hline Müzik öğretmenimi seviyorum & $\begin{array}{l}\text { Ö }(8,10,11,20,21,22,28,30,33,34,38,39,40 \text {, } \\
42,44,51,53,54,56,57,59,65,66,67,68,69,74, \\
75,78,81,82,87,89,94,99,102,103,104,107, \\
\text { Ö109, 110,111,114,118,129,136,137,138,139, } \\
140,143,145,147\end{array}$ & 53 & 36,04 \\
\hline Müzik dersinde davranışlarım olumlu & $\begin{array}{l}\text { Ö }(2,3,6,7,9,10,14,18,19,20,21,22,33,38,42, \\
46,51,57,64,82,83,84,97,101,105,117,118 \text {, } \\
122,129,130,131,136,140,147)\end{array}$ & 33 & 22,44 \\
\hline Çalgı çalıyorum & $\begin{array}{l}\text { Ö }(2,5,6,8,9,10,12,13,15,20,58,62,66,72,73, \\
86,88,89,95,99,100,108,109,111,130,136, \\
140,147)\end{array}$ & 30 & 20,4 \\
\hline Müzik dersi önemli & $\begin{array}{l}\text { Ö }(1,24,44,45,46,47,52,54,56,76,78,79,92 \text {, } \\
110,113,140,145)\end{array}$ & 19 & 12,92 \\
\hline Müzik dersinde konular öğreniyoruz & $\begin{array}{l}\text { Ö }(5,8,9,14,26,60,67,71,72,73,78,86,98,99 \text {, } \\
104,107,130,145)\end{array}$ & 18 & 12,24 \\
\hline Müziği seviyorum & $\begin{array}{l}\text { Ö }(1,11,16,24,27,47,52,65,67,78,89,91,119 \text {, } \\
147)\end{array}$ & 14 & 9,52 \\
\hline Müzik dersinde mutlu oluyorum & Ö $(1,2,4,7,8,10,13,17,41,84,105,131,134)$ & 13 & 8,84 \\
\hline Müzik dersi rahatlatıyor & Ö $(40,61,62,63,81,85,91,92,95,103)$ & 10 & 6,8 \\
\hline Çalgı çalmayı seviyorum & Ö $(9,13,59,66,79,108,128,136,143)$ & 9 & 6,12 \\
\hline Derste șarkı söylüyorum & Ö $(45,60,64,101,110,111,133,140)$ & 9 & 6,12 \\
\hline $\begin{array}{l}\text { Müzik dersinde öğretmenimiz } \\
\text { enstrüman çalıyor }\end{array}$ & Ö $(71,74,78,85,88,104,108,110)$ & 8 & 5,44 \\
\hline Şarkı söylemeyi seviyorum & Ö $(1,25,67,84,91,110,128,130)$ & 8 & 5,44 \\
\hline Çalgı çalamıyorum & Ö $(12,19,49,67,77,94,143)$ & 7 & 4,76 \\
\hline $\begin{array}{l}\text { Öğretmenimiz eğlendirerek ders } \\
\text { anlatıyor }\end{array}$ & Ö $(61,76,78,80,81,88,103)$ & 7 & 4,76 \\
\hline Müzik ders saati arttırılsın & Ö $(40,58,64,70,73,84,110)$ & 7 & 4,76 \\
\hline
\end{tabular}




\begin{tabular}{|c|c|c|c|}
\hline Müzik dersinde sevinç duyuyorum & Ö $(1,4,7,31,60,104,134)$ & 7 & 4,76 \\
\hline Müzik dersinde heyecanlanıyorum & Ö $(4,6,7,79,102,110)$ & 6 & 4,08 \\
\hline Öğretmenimiz çok güzel ders anlatıyor & $\ddot{O}(16,69,97,112,114,141)$ & 6 & 4,08 \\
\hline Müzik dersi iyi geçiyor & Ö $(2,5,71,81,87,132)$ & 6 & 4,08 \\
\hline Müzik dersini iple çekiyorum & Ö $(11,99,104,136,140)$ & 5 & 3,4 \\
\hline Müzik dersi sanattır & Ö $(43,67,145,146)$ & 4 & 2,72 \\
\hline Sesim güzel & Ö $(1,104,110,111)$ & 4 & 2,72 \\
\hline Müzik dersini sevmiyorum & Ö $(11,29,77)$ & 3 & 2,04 \\
\hline Müzik dersi eğitici & Ö $(44,102,104)$ & 3 & 2,04 \\
\hline Öğretmenimiz şarkılar söylüyor & $\ddot{O}(8,63,64)$ & 3 & 2,04 \\
\hline Yetenekliyim & $0 ̈(31,50,65)$ & 3 & 2,04 \\
\hline Yetenekli değilim & Ö $(29,77,94)$ & 3 & 2,04 \\
\hline Müzik dinlerim & Ö $(45,67,86)$ & 3 & 2,04 \\
\hline Üzgün olduğum zaman müzik dinlerim & Ö $(3,24,47)$ & 3 & 2,04 \\
\hline $\begin{array}{l}\text { Müzik öğretmenimiz sayesinde müziği } \\
\text { severim }\end{array}$ & Ö $(54,76,88)$ & 3 & 2,04 \\
\hline Müzik öğretmeni olmak istiyorum & Ö $(40,80)$ & 2 & 1,36 \\
\hline Müzik dersinde davranıșlarım olumsuz & Ö $(133,137)$ & 2 & 1,36 \\
\hline Müzik dinlerken mutlu oluyorum & $\ddot{O}(95,119)$ & 2 & 1,36 \\
\hline Müzik öğretmeni olmak istemiyorum & Ö (67) & 1 & 0,68 \\
\hline Sesim kötü & Ö (50) & 1 & 0,68 \\
\hline Çalgı çalamadığım zaman üzülüyorum & Ö (7) & 1 & 0,68 \\
\hline Müzik dersi mükemmel & Ö (9) & 1 & 0,68 \\
\hline Müzik dersi duygulu & Ö (92) & 1 & 0,68 \\
\hline Uygulamalı bir ders & Ö (17) & 1 & 0,68 \\
\hline Herkesin görmesi gerektiği bir ders & Ö (17) & 1 & 0,68 \\
\hline Yalnızlığı giderir & Ö (62) & 1 & 0,68 \\
\hline Müzik iyi ki var & Ö (91) & 1 & 0,68 \\
\hline Müzik temel ihtiyaçlardan biridir & Ö (92) & 1 & 0,68 \\
\hline Mutlu olduğum zaman müzik dinlerim & Ö (3) & 1 & 0,68 \\
\hline Canım sıkılınca müzik dinlerim & Ö (145) & 1 & 0,68 \\
\hline Yetenek gerektiren bir ders & Ö (30) & 1 & 0,68 \\
\hline Müzik dersi öğretici & Ö (34) & 1 & 0,68 \\
\hline Kendine güven kazandırır & Ö (7) & 1 & 0,68 \\
\hline Yabancı müzik severim & Ö (29) & 1 & 0,68 \\
\hline Müzik dinlerken içim geçiyor & Ö (95) & 1 & 0,68 \\
\hline
\end{tabular}

Tablo 1 incelendiğinde; örneklem grubundaki ortaokul 5. sınıf öğrencilerinin \%57,8'inin "müzik dersi zevkli", \%57,1'inin "müzik dersini seviyorum", \%36,04'ünün "müzik öğretmenimi seviyorum" görüşünü belirttikleri görülmektedir. Bu bulgular doğrultusunda ortaokul 5. sınıf öğrencilerinin öncelikle müzik dersini zevkli bulduğu, daha sonra müzik dersini ve müzik öğretmenini sevdiği söylenebilir.

Öğrencilerin görüşlerinden bazıları şöyledir;

Ö139 "Müzik dersi çok zevkli, çok eğlenceli, güzel, zevk verici, iyi bir ders."

Ö145 "Müzik dersi benim için eğlenceli ve zevkli olan bir derstir."

Ö10 "Müzik dersini çok seviyorum."

Ö48 "Müzik dersini çok seviyorum."

Ö22 "Öğretmenimi de çok seviyorum."

Ö66 "Müzik öğretmenimi de çok seviyorum."

Tablo 1'de yer alan bulgular doğrultusunda ortaokul 5. sınıf öğrencilerinin görüşlerinin ders, öğretmen ve öğrenci odaklı olduğu, bu görüşlerin de duyuşsal alana yönelik olduğu gözlenmiştir. 
Tablo 2. Örneklem Grubundaki 6. Sinıf Öğrencilerinin Müzik Dersine Yönelik Görüşleri

\begin{tabular}{|c|c|c|c|}
\hline Görüșler & İfade Eden Öğrenciler & $\mathbf{f}$ & $\%$ \\
\hline Müzik Dersini Seviyorum & $\begin{array}{l}\text { Ö }(1,2,3,4,5,6,8,9,10,11,13,14,15,17,20,21,24,25, \\
26,30,32,33,34,35,37,38,41,43,44,45,46,48,49, \\
50,51,52,55,56,57,58,59,60,61,62,63,64,65,69, \\
70,74,78,79,82,85,86,89,90,91,92,93,94,95,96, \\
97,98,99,100,102,104,106,107,108,109,110,112, \\
115,116,117,118,120,124,125,126,127,128,129, \\
131,138,139,140,141,143,147,148,149,150,152, \\
153)\end{array}$ & 98 & 63,7 \\
\hline Müzik Dersi Eğlenceli & $\begin{array}{l}\text { Ö }(2,3,6,7,10,14,15,18,19,23,28,31,33,34,36,39, \\
41,43,46,48,50,53,54,58,59,60,67,77,79,86,90, \\
95,96,98,100,103,104,106,107,111,114,115,116, \\
117,118,119,120,121,125,129,131,132,133,134, \\
135,136,138,142,145,149)\end{array}$ & 60 & 40,8 \\
\hline Müzik Dersi Önemlidir & $\begin{array}{l}\text { Ö }(1,4,5,10,11,12,13,19,20,21,22,25,28,29,31,32, \\
36,39,40,42,45,48,51,53,54,57,60,61,63,68,69, \\
98,105,112,113,115,116,119,123,124,125,132,137, \\
142,144,146,147,148,151)\end{array}$ & 49 & 22,77 \\
\hline Müzik Dersi Rahatlatıyor & $\begin{array}{l}\text { Ö }(15,18,20,23,27,28,29,31,32,33,40,49,53,54,56 \text {, } \\
57,58,59,63,64,75,77,84,86,87,97,98,115,122 \text {, } \\
131,134,146,147,148,150)\end{array}$ & 35 & 22,75 \\
\hline Müzik Öğretmenimi Seviyorum & $\begin{array}{l}\text { Ö }(15,18,23,26,45,46,53,54,59,61,69,70,74,75,77, \\
79,82,83,85,86,88,96,109,111,115,117,118,125, \\
127,128)\end{array}$ & 30 & 19,5 \\
\hline $\begin{array}{l}\text { Müzik Dersi ile ilgili } \\
\text { davranışlarım olumlu }\end{array}$ & $\begin{array}{l}\text { Ö }(26,34,35,39,44,45,46,47,52,55,57,58,64,65,92, \\
94,101,111,113,120,123,129,135,136,138,139,141 \text {, } \\
152)\end{array}$ & 28 & 18,2 \\
\hline $\begin{array}{l}\text { Müzik Dersinde Çalgı Çalmayı } \\
\text { Seviyorum }\end{array}$ & $\begin{array}{l}\text { Ö }(18,24,30,31,35,38,41,45,49,50,72,80,83,92,98, \\
100,106,110,114,116,126,128,130,135,137,152)\end{array}$ & 26 & 16,9 \\
\hline Müzik Dersinde Çalgı Çalıyorum & $\begin{array}{l}\text { Ö }(10,11,21,24,28,37,51,67,69,77,79,94,95,96 \text {, } \\
101,102,103,104,107,113,127,120,147,149)\end{array}$ & 24 & 15,6 \\
\hline Müzik Dersi Güzel & $\begin{array}{l}\text { Ö }(2,23,28,30,36,37,39,44,53,57,66,71,75,97,102 \text {, } \\
107,109,133,139)\end{array}$ & 19 & 12,35 \\
\hline $\begin{array}{l}\text { Müzik dersine yönelik hangi } \\
\text { konuların işlendiğini anlatan } \\
\text { öğrenciler }\end{array}$ & $\begin{array}{l}\text { Ö }(3,7,10,11,15,18,21,23,28,36,39,41,104,107 \text {, } \\
108,133,137,143,147)\end{array}$ & 19 & 12,35 \\
\hline Müzik Dinliyorum & $\begin{array}{l}\text { Ö }(26,27,38,57,78,80,84,98,100,109,112,115,119 \text {, } \\
123,131,132,144)\end{array}$ & 17 & 11,05 \\
\hline Müzik Ders Saati Arttırılsın & Ö $(1,3,4,5,6,8,9,19,43,49,51,54,97,98,127,143)$ & 16 & 10,4 \\
\hline Müzik Dersinde Mutlu Oluyorum & Ö $(2,14,16,42,56,57,61,65,68,89,94,108,136)$ & 13 & 8,45 \\
\hline Müziği Seviyorum & Ö $(1,18,31,45,48,52,98,110,124,126,127,141,144)$ & 13 & 8,45 \\
\hline $\begin{array}{l}\text { Müzik Dersinde Öğretmenimiz } \\
\text { Enstrüman Çalıyor }\end{array}$ & Ö $(24,30,50,53,60,61,80,86,106,128,135,136)$ & 12 & 7,8 \\
\hline $\begin{array}{l}\text { Müzik Dersi ile ilgili } \\
\text { davranıșlarım olumsuz }\end{array}$ & Ö $(48,52,58,79,91,93,111,114,117,126,139)$ & 11 & 7,15 \\
\hline Müzik Dersi Zevkli & Ö $(2,28,30,32,36,73,76,106,127,149,150)$ & 11 & 7,15 \\
\hline $\begin{array}{l}\text { Müzik Dersinde Çalgı } \\
\text { Çalmıyorum }\end{array}$ & Ö $(32,33,44,57,64,78,84,144,44,133)$ & 10 & 6,5 \\
\hline Müzik Dersini Sevmiyorum & Ö $(72,74,80,81,87,88,111,144,153)$ & 9 & 5,85 \\
\hline Müzik Dersine İlgiliyim & Ö $(8,31,35,37,48,62,83,98,137)$ & 9 & 5,85 \\
\hline $\begin{array}{l}\text { Müzik Dersi Yerine Başka Ders } \\
\text { Getirilsin }\end{array}$ & $\ddot{O}(71,72,87,88,99)$ & 5 & 3,25 \\
\hline Müzik Öğretmenimi Sevmiyorum & Ö $(71,73,76,80,81)$ & 5 & 3,25 \\
\hline Müzik Dersi Kolay & Ö $(147,148,149)$ & 3 & 1,95 \\
\hline Sesim Güzel & $\ddot{O}(50,52,61)$ & 3 & 1,95 \\
\hline Müzik Dersi Heyecanlı & Ö $(57,65)$ & 2 & 1,3 \\
\hline
\end{tabular}




\begin{tabular}{llrr}
\hline Müzik Dersi Önemsiz & Ö (87) & 1 & 0,65 \\
\hline Müzik Dersi Zevksiz & Ö (76) & 1 & 0,65 \\
\hline Müzik Dersine İlgi Duymuyorum & $\ddot{O ~(39) ~}$ & 1 & 0,65 \\
\hline Müzik Dersinin Sesi Geliștiriyor & Ö (42) & 1 & 0,65 \\
\hline Müzik sinıfi bulunmalı & Ö (125) & 1 & 0,65 \\
\hline Müzik Dersi Zor & $\ddot{O}(39)$ & 1 & 0,65 \\
\hline Sesim Kötü & Ö (2) & 1 & 0,65 \\
\hline
\end{tabular}

Tablo 2 incelendiğinde; örneklem grubundaki ortaokul 6. sınıf öğrencilerinin \%63,7'sinin "müzik dersi seviyorum", \%40,8'inin "müzik dersi eğlenceli", \%22,77'sinin "müzik dersi önemlidir" görüşünü belirttikleri görülmektedir. Bu bulgular doğrultusunda ortaokul 6. sinıf öğrencilerinin öncelikle müzik dersini sevdiği, müzik dersini eğlenceli ve önemli bir ders olarak gördükleri söylenebilir.

Öğrencilerin görüşlerinden bazıları şöyledir;

Ö8 "Müzik dersini çok seviyorum."

Ö13 “Müzik dersi en çok sevdiğim derslerden biri. Çünkü müzik dersinde şarkılar söylüyor ve müzikte bazı șeyler öğreniyoruz."

Ö48 "Müzik dersi bizim sınıfımızda çok eğlenceli geçer. Eğlenceli geçtiği içinde müziğe her geçen gün daha da ilgim artıyor."

Ö67 "Ben müzik dersinde çok eğlenirim."

Ö19 "Müzik dersi önemli bir derstir."

Ö54 "Müzik dersinin Türkçe, matematik, fen vb. dersler kadar önemli olduğunu düşünüyorum."

Tablo 2'de yer alan bulgular doğrultusunda ortaokul 6. sınıf öğrencilerinin görüşlerinin ders, öğretmen ve öğrenci odaklı olduğu, bu görüşlerin duyuşsal alana yönelik olduğu gözlenmiştir.

Tablo 3. Örneklem Grubundaki 7. Sinıf Öğrencilerinin Müzik Dersine Yönelik Görüşleri

\begin{tabular}{|c|c|c|c|}
\hline Görüșler & İfade Eden Öğrenciler & f & $\%$ \\
\hline Müzik Dersini Seviyorum & $\begin{array}{l}\text { Ö }(3,4,6,7,8,10,11,12,14,15,17,18,21,22, \\
23,24,26,27,28,31,32,33,34,35,36,37,41, \\
44,45,46,47,48,49,50,51,53,55,56,61,63, \\
64,65,66,67,70,72,73,81,82,83,84,85,86, \\
89,91,92,93,96,97,99,100,101,102,104,105, \\
106,107,110,111,112,116,121,123,122,126, \\
128,129,132,133,134,135,137,138,139,141, \\
144,146,147,148)\end{array}$ & 89 & 59,63 \\
\hline Müzik Dersi Eğlenceli & $\begin{array}{l}\text { Ö }(4,5,11,13,16,17,20,30,32,33,34,36,40, \\
41,51,53,55,58,62,64,65,72,80,86,87,88, \\
91,93,96,99,102,107,110,111,112,113,114 \text {, } \\
117,118,120,124,127,136,139,140,142,143 \text {, } \\
144,145)\end{array}$ & 49 & 32,83 \\
\hline Müzik Dersi ile ilgili davranışlarım olumlu & $\begin{array}{l}\text { Ö }(1,6,7,8,9,10,11,12,15,16,17,18,20,30, \\
32,35,36,37,38,41,43,44,48,50,51,53,54, \\
56,58,66,80,84,86,87,91,94,97,101,108, \\
117)\end{array}$ & 40 & 26,8 \\
\hline Müzik Dersi Önemli & $\begin{array}{l}\text { Ö }(2,4,5,7,8,9,10,12,13,14,17,18,20,27,29, \\
33,51,52,56,60,65,69,70,75,82,86,97,115 \text {, } \\
118,121,125,126,128,129,132,147)\end{array}$ & 36 & 24,12 \\
\hline Müzik Öğretmenimi Seviyorum & $\begin{array}{l}\text { Ö }(4,5,6,8,12,23,32,33,34,35,36,40,44,45, \\
47,49,50,51,53,56,65,79,85,87,92,94,96, \\
98,100,103,104,105,106,108,112,116,117, \\
119,122,123,126,127,128,131,133,134,143 \text {, } \\
145)\end{array}$ & 35 & 23,45 \\
\hline Müzik Dersi Güzel & $\begin{array}{l}\text { Ö }(13,21,30,32,34,48,52,55,72,79,83,91,93, \\
98,99,102,107,110,111,112,113,114,117, \\
118,122,124,127,131,136,145,150)\end{array}$ & 31 & 20,77 \\
\hline Müzik Dersi Zevkli & $\begin{array}{l}\text { Ö }(5,6,11,13,16,28,31,34,35,36,37,43,48 \text {, } \\
49,54,55,58,63,67,83,91,92,99,100,110,\end{array}$ & 30 & 20,1 \\
\hline
\end{tabular}


Müzik Dersinde Çalgı Çalıyorum

Müzik Dersi Rahatlatıyor

Müzik Dersinde Çalgı Çalmayı Seviyorum

Müzik Dinliyorum

Müzik Dersinde Öğretmenimiz Enstrüman Çalıyor

Müzik Dersine İlgiliyim

Müzik dersine yönelik hangi konuların işlendiğini anlatan öğrenciler

Müziği Seviyorum

Müzik Dersinde Çalgı Çalmıyorum

Müzik Dersinde Mutluyum

Müzik Dersinde Şarkı Söylüyorum

Müzik Dersini Sevmiyorum

Müzik Dersinde Öğretmeninin Sınav

Sisteminden Yakınan Öğrenciler

Müzik Ders Saati Arttırılsın

Müzik Dersi Kolay

Şarkı Söylüyorum

Müzik Dersi geliştiriyor

Müzik Dersi Heyecanlı

Müzik Dersi Yetenek Gerektirir

Müzik Öğretmenimi Sevmiyorum

Müzik Dersinde Çalgı Çalmayı Sevmiyorum

Müzik Dersi ile ilgili davranışlarım olumsuz

Müzik Dersine İlgi duymuyorum

Müzik Dersi Zor

Müzik Dersinde başarılıyım

Müzik Dersi sosyalleștirir

Müzik Dersi ilham kaynağıdır

Müzik Dersinde şarkı söylüyoruz

Şarkı söylemeyi seviyorum

Müzik Dersi Yerine Başka Ders Getirilsin

Müzik Dersi Önemsiz

Müzik Dersinde Șarkı Söylemiyorum

Müzik Dinlemiyorum

Müzik Dersinde bașarısızım

Müzik Dersi “Ciddiyet" İsteyen Bir Ders

Müzik Dersi verimli

Müzik Sınıfı Bulunuyor

Müzik Öğretmeni olmak isterdim

Çalgı Aletlerini seviyorum

$116,119,127,139,142)$

Ö $(4,14,18,21,22,24,50,57,66,67,69,70,71$, $72,80,84,91,96,99,100,103,105,108,110,2818,76$ $111,117,118,124)$

Ö $(6,9,10,17,34,47,52,61,65,73,76,82,86$, $99,107,108,109,118,120,122,126,129,136,25 \quad 16,75$ $141,150)$

Ö $(3,7,8,15,27,29,33,39,40,43,47,80,89,98$, $99,109,114,117,119,120,126,134,139,143)$

Ö $(1,4,7,8,10,22,32,42,47,48,60,63,69,75$, $76,109,111,112,116,118,135,136)$ Ö $(1,4,6,8,21,22,31,33,35,37,48,50,52,71,20$
$81,87,92,93,103,108)$

Ö $(6,11,14,17,18,33,36,38,39,47,56,60,62$, $71,73,109,121,128,129,135)$

$20 \quad 13,4$

Ö $(18,21,33,38,43,47,56,57,93,100,107$, $109,128,129,130,142)$

Ö $(1,10,15,17,22,23,34,40,57,59,69,74,80,1610,72$ $109,126,150)$

Ö $(44,60,61,63,66,70,79,86,96,106,113$,

$123,126,144,150)$

$15 \quad 10,05$

Ö $(7,9,34,35,45,53,55,73,78,86$, , 120, 121, $122,124,141)$

Ö $(2,3,7,21,15,43,50,56,64,81,102,109) \quad 12 \quad 8,04$

Ö $(1,25,42,75,95,100,101,103,106,113,150) \quad 11 \quad 7,37$

Ö $(1,2,3,6,41,47,84,85,98,100)$

$10 \quad 6,7$

Ö $(4,10,16,26,52,107,122,137,138) \quad 9 \quad 6,03$

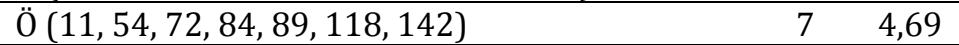

Ö $(1,3,8,21,82,112) \quad 6 \quad 4,02$

Ö $(52,76,90,128,140,146) \quad 6 \quad 4,02$

Ö $(10,58,63,76,95) \quad 5 \quad 3,35$

Ö $(18,20,27,96,110) \quad 5 \quad 3,35$

Ö $(95,97,104) \quad 3 \quad 3,35$

Ö $(74,75,89) \quad 3 \quad 3,35$

Ö $(20,43,94) \quad 3 \quad 3,35$

Ö $(3,62,150) \quad 3 \quad 3,35$

Ö $(11,89) \quad 2 \quad 1,34$

$\ddot{O}(45,117) \quad 2 \quad 1,34$

Ö $(52,119) \quad 2 \quad 1,34$

Ö $(90,150) \quad 2 \quad 1,34$

Ö $(113,121) \quad 2 \quad 1,34$

Ö $(114,120) \quad 2 \quad 1,34$

$\begin{array}{lll}0 ̈(59) & 1 & 0,67\end{array}$

Ö (25) 110,67

Ö (15) 110,67

Ö (15) 110,67

Ö (60) 110,67

Ö (28) 110,67

Ö (50) 110,67

Ö (137) 110,67

Ö (126) 110,67

Ö (126) 110,67

Tablo 3 incelendiğinde; örneklem grubundaki ortaokul 7. sınıf öğrencilerinin \%59,63'ünün "müzik dersini seviyorum", \%32,83'ünün "müzik dersi eğlenceli", \%26,8'inin "müzik dersi ile ilgili davranışlarım olumlu" görüşünü belirttikleri görülmektedir. Bu bulgular doğrultusunda ortaokul 7 . 
sınıf öğrencilerinin öncelikle müzik dersini sevdiği, müzik dersini eğlenceli buldukları ve müzik dersi ile ilgili davranışlarını olumlu olarak gördükleri söylenebilir.

Öğrencilerin görüşlerinden bazıları șöyledir;

Ö4 "Ben müzik dersini çok seviyorum."

Ö31 "Ben müzik dersini çok seviyorum en çok sevdiğim dersler arasında."

Ö93 "Bana göre müzik dersi çok eğlenceli bir derstir."

Ö112 "Müzik dersinde çok eğleniyorum."

Ö7 "Dersle ilgili davranışlarım ise iyidir."

Ö41 "Müzik dersine karşı sorumluluklarımı yerine getirmeye çalışıyorum. Öğretmenime saygılı davranıyor ve ödevlerimi yapmaya çalışıyorum."

Tablo 3'te yer alan bulgular doğrultusunda ortaokul 7. sınıf öğrencilerinin görüşlerinin ders, öğretmen ve öğrenci odaklı olduğu, bu görüşlerin de duyuşsal alana yönelik olduğu gözlenmiştir.

Tablo 4. Örneklem Grubundaki 8. Sinıf Öğrencilerinin Müzik Dersine Yönelik Görüşleri Görüșler

\begin{tabular}{|c|c|c|c|}
\hline Görüşler & İfade Eden Öğrenciler & f & $\%$ \\
\hline Müzik Dersini Seviyorum & $\begin{array}{l}\text { Ö }(1,2,3,9,10,13,15,16,17,18,19,20,25,26,27,30,31, \\
32,33,34,36,37,38,39,40,41,42,46,50,52,53,54,56,57, \\
62,63,66,67,69,70,71,72,74,75,76,78,82,84,90,91,92, \\
93,96,97,98,99,100,102,103,104,105,108,109,111, \\
114,115,116,119,120,123,124,125,127,129,131,132, \\
133,134,135,136,138,139,140,141,143,145,148,154, \\
156,158,159,162,163,164,166,168,169,170,171,172, \\
177,180,181,183,184,185,186,188,191,192)\end{array}$ & 110 & 57,2 \\
\hline Müzik Dersi Rahatlatıyor & $\begin{array}{l}\text { Ö }(1,2,4,5,7,8,12,15,17,18,30,32,38,39,40,41,45,48, \\
51,54,55,57,58,60,66,67,68,69,71,72,78,80,84,85,87, \\
88,91,92,93,94,101,106,107,108,110,112,113,114, \\
116,122,124,127,128,130,144,146,147,148,150,153, \\
156,158,160,161,163,164,165,169,176,177,181,184, \\
185,186,187,188,191,194)\end{array}$ & 78 & 40,56 \\
\hline Müzik Dersi Önemli & $\begin{array}{l}\text { Ö }(1,3,4,6,9,10,12,15,16,18,19,20,24,26,31,32,33,37, \\
38,39,41,52,64,65,66,69,75,76,77,80,84,85,86,88,90, \\
92,93,94,98,99,103,106,107,108,110,114,118,120, \\
122,123,124,126,127,129,130,132,133,141,157,163 \text {, } \\
165,172,173,182,191)\end{array}$ & 65 & 33,8 \\
\hline Müzik Dersi Eğlenceli & $\begin{array}{l}\text { Ö }(4,13,20,26,30,32,39,41,47,51,63,64,65,66,67,68, \\
69,70,72,74,75,76,77,80,82,85,86,89,97,99,100,102 \text {, } \\
103,107,109,111,114,115,116,117,118,119,125,128, \\
130,131,132,133,134,144,147,148,150,156,159,161 \text {, } \\
165,169,175,177,185)\end{array}$ & 61 & 31,72 \\
\hline Müzik Dinliyorum & $\begin{array}{l}\text { Ö }(7,9,12,30,32,38,46,47,49,52,56,57,61,62,65,66,69, \\
71,72,74,75,82,83,85,90,98,99,110,112,113,123,124, \\
126,127,141,145,149,152,161,163,164,166,168,169, \\
170,171,172,174,178,180,182,183,189,190,192,193)\end{array}$ & 56 & 29,12 \\
\hline Müzik Dersi Güzel & $\begin{array}{l}\text { Ö }(2,3,7,11,15,23,25,34,39,40,43,70,73,74,75,78,79, \\
80,81,83,86,89,92,109,112,113,114,131,147,155,162 \text {, } \\
165,167,173,174)\end{array}$ & 35 & 18,2 \\
\hline $\begin{array}{l}\text { Müzik Dersi ile ilgili } \\
\text { davranışlarını olumlu ifade } \\
\text { eden öğrenciler }\end{array}$ & $\begin{array}{l}\text { Ö }(15,18,34,37,41,42,43,47,53,65,68,70,71,82,84,87 \text {, } \\
91,95,96,102,103,105,108,115,120,121,134,135,137 \text {, } \\
139,147,152,155)\end{array}$ & 33 & 17,16 \\
\hline Müzik Dersi Zevkli & $\begin{array}{l}\text { Ö }(20,21,25,30,33,34,39,65,67,70,88,89,97,99,100 \text {, } \\
102,108,111,119,130,132,134,163,175,177,181,185)\end{array}$ & 27 & 14,04 \\
\hline Müzik Dersinde Mutluyum & $\begin{array}{l}\text { Ö }(4,9,13,15,47,52,65,68,71,78,79,80,94,95,97,106, \\
114,132,134,137,154,158,159,182,183,187,188)\end{array}$ & 27 & 14,04 \\
\hline $\begin{array}{l}\text { Müzik Öğretmenimi } \\
\text { Seviyorum }\end{array}$ & $\begin{array}{l}\text { Ö }(2,13,14,19,25,27,29,30,33,36,37,40,42,53,66,71 \text {, } \\
73,82,128,135,136,138,145,162,163,167)\end{array}$ & 26 & 13,52 \\
\hline $\begin{array}{l}\text { Müzik Dersine yönelik hangi } \\
\text { konuların işlendiğini anlatan } \\
\text { öğrenciler }\end{array}$ & $\begin{array}{l}\text { Ö }(9,23,24,26,29,30,34,35,36,37,38,39,42,66,67,70 \text {, } \\
76,77,79,81,95,132,140,156)\end{array}$ & 24 & 12,48 \\
\hline
\end{tabular}




\begin{tabular}{|c|c|c|c|}
\hline $\begin{array}{l}\text { Müzik Dersinde Çalgı Çalmayı } \\
\text { Seviyorum }\end{array}$ & $\begin{array}{l}\text { Ö }(27,31,32,46,60,69,73,79,85,97,98,99,100,108,109, \\
111,115,122,124,125,138,178,180)\end{array}$ & 23 & 11,96 \\
\hline $\begin{array}{l}\text { Müzik Dersinde Şarkı } \\
\text { Söylüyorum }\end{array}$ & $\begin{array}{l}\text { Ö }(13,19,21,46,47,56,72,132,137,142,149,163,164, \\
176,177,179,185,186)\end{array}$ & 18 & 9,36 \\
\hline $\begin{array}{l}\text { Müzik Dersinde } \\
\text { Öğretmenimiz Enstrüman } \\
\text { Çalıyor }\end{array}$ & $\begin{array}{l}\text { Ö }(78,116,121,124,125,128,130,131,133,134,137,144, \\
147,149,162,163,173,174)\end{array}$ & 18 & 9,36 \\
\hline Müzik Dersini Sevmiyorum & $\begin{array}{l}\text { Ö }(22,24,26,28,35,39,50,61,96,142,149,174,178,179 \text {, } \\
193)\end{array}$ & 15 & 7,8 \\
\hline $\begin{array}{l}\text { Müzik Dersinde Çalgı } \\
\text { Çalıyorum }\end{array}$ & $\begin{array}{l}\text { Ö }(27,47,50,65,72,78,89,121,123,127,132,146,169 \text {, } \\
185,191)\end{array}$ & 15 & 7,8 \\
\hline Müziği Seviyorum & Ö $(10,58,66,80,93,99,108,112,114,144,173,191,192)$ & 13 & 6,76 \\
\hline $\begin{array}{l}\text { Müzik Dersi duygu ve } \\
\text { düşünceleri anlatır }\end{array}$ & $\ddot{O}(2,4,5,8,10,12,31,66,101,118,127,128,129)$ & 13 & 6,76 \\
\hline Müzik Dersine İlgiliyim & Ö $(34,46,57,60,94,98,99,109,111,115,122,171)$ & 12 & 6,24 \\
\hline Sesim kötü & Ö $(11,47,49,59,100,140,141,172,180,189)$ & 10 & 5,2 \\
\hline Müzik Dersi Zor & Ö $(11,39,64,100,141,151,159,179)$ & 8 & 4,16 \\
\hline $\begin{array}{l}\text { Müzik Dersinde Şarkı } \\
\text { Söylemiyorum }\end{array}$ & Ö $(10,57,62,95,170,184,189,190)$ & 8 & 4,16 \\
\hline Müzik Dersi Kolay & Ö $(11,94,96,125,131,133,159)$ & 7 & 3,64 \\
\hline $\begin{array}{l}\text { Müzik Dersinde Çalgı } \\
\text { Çalmıyorum }\end{array}$ & Ö $(95,99,114,116,117,152,155)$ & 7 & 3,64 \\
\hline Müzik Dersi Ĕ̆itici-öğretici & Ö $(9,27,68,106,127,119,133)$ & 7 & 3,64 \\
\hline Șarkı Söylemiyorum & $O ̈(98,99,100,127,141,172)$ & 6 & 3,12 \\
\hline Müzik Ders Saati Arttırılsın & $O ̈(40,78,105,135,185)$ & 5 & 2,6 \\
\hline Müzik Dersi Seçmeli Olsun & Ö $(22,44,45,48,49)$ & 5 & 2,6 \\
\hline $\begin{array}{l}\text { Müzik Öğretmeni olmak } \\
\text { istiyorum }\end{array}$ & Ö $(11,46,94,96,141)$ & 5 & 2,6 \\
\hline Müzik Dersi bir sanattır & Ö $(12,32,88,161,175)$ & 5 & 2,6 \\
\hline Müzik Dersi Heyecanlı & Ö $(14,68,94,159)$ & 4 & 2,08 \\
\hline Müzik dersi geliştirir & Ö $(12,31,121)$ & 3 & 1,56 \\
\hline Sesim güzel & Ö $(11,18,56)$ & 3 & 1,56 \\
\hline Müzik Dersi Önemsiz & $\ddot{O}(117,193)$ & 2 & 1,04 \\
\hline Müzik Dersine İlgili değilim & $O ̈(140,142)$ & 2 & 1,04 \\
\hline $\begin{array}{l}\text { Müzik sınıfının bulunması } \\
\text { gerekir }\end{array}$ & Ö $(84,135)$ & 2 & 1,04 \\
\hline Müzik dersinde başarısızım & Ö $(59,70)$ & 2 & 1,04 \\
\hline $\begin{array}{l}\text { Müzik dersi yetenek } \\
\text { gerektirir }\end{array}$ & Ö $(64,160)$ & 2 & 1,04 \\
\hline $\begin{array}{l}\text { Müzik Dersi Yerine Başka } \\
\text { Ders Getirilsin }\end{array}$ & Ö (22) & 1 & 0,52 \\
\hline $\begin{array}{l}\text { Müzik dersi çok gururlu ve } \\
\text { onurlu bir derstir }\end{array}$ & Ö (42) & 1 & 0,52 \\
\hline
\end{tabular}

Tablo 4 incelendiğinde; örneklem grubundaki ortaokul 8. sınıf öğrencilerinin \%52,2'sinin "müzik dersini seviyorum", \%40,56'sının "müzik dersi rahatlatıyor", \%33,8'inin "müzik dersi önemli" görüşünü belirttikleri görülmektedir. Bu bulgular doğrultusunda ortaokul 8. sınıf öğrencilerinin öncelikle müzik dersini sevdiği, müzik dersini rahatlatan ve önemli bir ders olarak gördükleri söylenebilir.

Öğrencilerin görüşlerinden bazıları şöyledir;

Ö9 "Ben şahsen müzik dersini çok seviyorum çok keyifli anlar yaşıyoruz."

Ö30 “Müzik dersini çok seviyorum. Bu SBS'ye hazırlanma sürecinde müzik dersi içimizi ferahlatan,

bizi dinlendirip oh çektiren bir ders. Her Perşembe'yi iple çekiyorum."

Ö40 "Müzik dersi çok rahatlatıcı bir ders."

Ö146 "Müzik dersinde insan çok rahatlıyor. Müzik sesleri duymak insana huzur veriyor."

Ö1 "Müzik dersi benim için çok önemlidir." 
Ö76 "Bence müzik dersi önemli derslerimizden bir tanesi."

Tablo 4'te yer alan bulgular doğrultusunda ortaokul 8. sınıf öğrencilerinin görüşlerinin ders, öğretmen ve öğrenci odaklı olduğu, bu görüşlerin de duyuşsal alana yönelik olduğu gözlenmiştir.

\section{SONUÇ ve ÖNERILER}

\section{Sonuçlar}

Araştırma bulguları doğrultusunda;

- Ortaokul 5. sınıf öğrencilerinin öncelikle müzik dersini zevkli bulduğu, müzik dersini ve müzik öğretmenini sevdiği,

- Ortaokul 6. sınıf öğrencilerinin öncelikle müzik dersini sevdiği, müzik dersini eğlenceli ve önemli bir ders olarak gördükleri,

- Ortaokul 7. sınıf öğrencilerinin öncelikle müzik dersini sevdiği, müzik dersini eğlenceli buldukları ve müzik dersi ile ilgili davranışlarını olumlu olarak gördükleri,

- Ortaokul 8. sınıf öğrencilerinin öncelikle müzik dersini sevdiği, müzik dersini rahatlatan ve önemli bir ders olarak gördükleri, sonuçlarına ulașılmıștır.

Ayrıca ortaokul 5. 6. 7. ve 8. sınıf öğrencilerinin konuya ilişkin görüşlerinin ders, öğretmen ve öğrenci odaklı olduğu, bu görüşlerin de duyuşsal alana yönelik olduğu tespit edilmiştir.

\section{Öneriler}

Araştırma sonuçları doğrultusunda ortaokul 5. 6. 7. 8. sınıf öğrencilerinin müzik derslerinde öğrencilerin duyuşsal alana yönelik belirginleşen görüşlerinin yanında;

- Bilişsel alanın uygulama basamağına yönelik görüşlerinin oluşmasına ve gelişmesine katkı sağlamak için ders ve ders dışında bizzat içerisinde yer alarak teorik bilgilerini uygulamaya aktarabileceği araștırma inceleme etkinliklerine katılımı sağlanmalıdır. Bu kapsamda öğrencilerin analiz-sentez aşamasında ders konuları ile ilgili görüşlerinin ve zihinsel becerilerinin oluşması, gelişmesi ve bilgilerinin yapılandırılabilmesi için uygulamalı etkinliklere yönlendirilmesi, değerlendirme aşamasında ise görüşlerini, bilgi ve beceri düzeylerinin gelişimini ölçmeye yönelik süreç odaklı değerlendirme çalışmalarının yapıldığı, sınıf içi çalışmaların değerlendirildiği ve müzik dersi konularına yönelik farkındalık yaratan etkinliklere yer verilmesi önerilmektedir.

- Devinişsel alanın algılama aşamasında görüşlerinin oluşmasına ve gelişmesine katkı sağlamak için uygun ipuçlarını seçme, belli bir hareket için hazır olma, nasıl yapıldığını dikkatle izleme, gözleme, tanıma, tanımlama, kurulum aşamasında görüşlerinin oluşmasına ve gelişmesine katkı sağlamak için hazır bulunuşluk düzeyi farkındalığı, kılavuzlama basamağında aşamasında görüşlerinin oluşmasına ve gelişmesine katkı sağlamak için müzik öğretmenini taklit etmesi, deneme-yanılma yöntemelerini kullanabilmesi, beceri haline getirme aşamasında görüşlerinin oluşmasına ve gelişmesine katkı sağlamak için çalgısını sergilemesi, duruma uydurma aşamasında görüşlerinin oluşmasına ve gelişmesine katkı sağlamak için ise temel müzik yazı ve öğelerinin yer aldığı, basit çok sesli şarkıların seslendirildiği, ritim çalgılarının kullanılabildiği, çalgı becerilerini geliştirdiği ve kendi ezgilerini oluşturabildiği etkinliklere katılımlarının sağlanması önerilmektedir.

\section{KAYNAKÇA}

Akgül Barış, D. (2002). Müzik Eğitimi Alan ve Almayan Lise Öğrencilerinin Benlik Tasarımı Düzeylerinin Çeșitli Değişkenlere Göre İncelenmesi (Yayınlanmamış Doktora Tezi). Ankara: Gazi Üniversitesi Fen Bilimleri Enstitüsü.

Aksu, M. (2005). "Eğitim Fakültelerinin Değişen Rolleri ve Avrupa Boyutu" (Eğitim Fakültelerinde Yeniden Yapılandırmanın Sonuçları ve Ögretmen Yetiştirme Sempozyumu, 22- 23-24 Eylül 2005), Bildiriler, Gazi Üniversitesi Eğitim Fakültesi, Ankara, s.25.

Aktaş, A. ve Bulut, D. (2012) İlköğretim I. Kademe 2. Devre Müzik Dersine Yönelik Öğretmen Görüşleri: Niğde İli Örneği, X. Ulusal Müzik Eğitimi Sempozyumu, 25-27 Nisan, Niğde. (s.418-437)

Biber Öz, N.( 2001) İnsanın Kültürel Gelişiminde Müzik Eğitiminin Önemi Uludağ Üniversitesi Eğitim Fakültesi Dergisi Cilt: XIV, Sayı: 1. 
Çilden Ş. (2001), Müzik, Çocuk Gelişimi Ve Öğrenme G.Ü. Gazi Eğitim Fakültesi Dergisi Cilt 21, Sayı 1.

Dinçer, İ. (1992) Çocuk Gelişimi ile İlgilenenler İçin Müzik El Kitabı, İstanbul: Ya-Pa Yayınları.

Gel, H.Y. (1994). Çağdaș Eğitimde Sanat, Çağdaș Yaşamı Destekleme Derneği Yayınları, (http://www.egitim.aku.edu.tr/gel.htm), Erişim Tarihi: 07.03.2010. s.37-51

Gedikli, E. (2007) Okul Öncesi Müzik Etkinlikleri Eğitimi, Bursa: Ezgi Kitabevi.

Göğüş G. (2008) İlköğretim I. Kademe Müzik Eğitiminde Öğretmenin Etkinliği Uludağ Üniversitesi Eğitim Fakültesi Dergisi XXI (2).

Göğüș G. (2009), Müzik Yeteneğinin Geliștirilmesinde Küçük Yașlarda Eğitime Bașlamanın Önemi Uludağ Üniversitesi Eğitim Fakültesi Dergisi XXII (1).

Khan, S. I. (1994) Müzik İnsan ve Evren Arasındaki Küprü, İstanbul: Arıtan Yayınevi.

Kılıç I. (2012) Okul Öncesi Müzik Eğitimi, Ankara, Pegem Akademi.

Kocabaş A. (1997), Temel Eğitim Il. Kademe Öğrencileri İçin Müziğe İlişkin Tutum Ölçeğinin Geçerlik ve Güvenirlik Çalışması Hacettepe Üniversitesi Eğitim Fakültesi Dergisi 13. (s.141-145)

Kocabaş A. ve Selçioğlu E. (2003) İlköğretim 4. ve 5. Sınıf Müzik Dersinin Gerçekleşme Düzeyine İlişkin Öğrenci Görüşleri, KKEFD, Sayı: 8.

MEB. (2007). İlköğretim müzik dersi öğretim programı. Ankara: Devlet Kitapları Müdürlüğü.

Özsoy, V. (2003) Görsel Sanatlar Eğitimi, Ankara: Gündüz Eğitim ve Yayıncılık Turizm Sanayi Ticaret Ltd. Şti.

Say A. (2006) Müziğin Kitabı, Ankara.

Şendurur Y. ve Akgül Barış D. (2002) Müzik Eğitimi ve Çocuklarda Bilişsel Başarı Gazi Eğitim Fakültesi Dergisi Cilt 22, Sayı 1. (s.165-174)

Uçal Canakay, E. (2006), Müzik Teorisi Dersine İliş̧kin Tutum Ölçeği Geliştirme, Ulusal Müzik Eğitimi Sempozyumu Bildirisi Pamukkale Üniversitesi Eğitim Fakültesi, Denizli.

Uçan, A. (1997) Müzik Eğitimi, Ankara: Müzik Ansiklopedisi Yayınları.

Uçan, A. (2005) Müzik Eğitimi, Ankara: Müzik Ansiklopedisi Yayınları.

Yıldırım, A., ve Şimşek, H. (2006). Sosyal Bilimlerde Nitel Araştırma Yöntemleri. Ankara: Seçkin Yayıncılık. 